\title{
The Impact Mechanism between the Incentive to Hold Financial Assets, Financial Risk and Innovation Activities
}

\author{
Yuying Gao ${ }^{1}$, Shanyue $\mathrm{Jin}^{2 *}$ \\ ${ }^{1}$ College of Economics and Management, Pingdingshan University, China \\ ${ }^{2}$ College of Business, Gachon University, South Korea \\ lgyy3990@126.com,2E-mail; 2*jsyrena0923@gachon.ac.kr(Corresponding author)
}

\begin{abstract}
With the deepening of economic globalization and financialization of China' s economy, the proportion of financial assets held by non-financial enterprises has gradually increased, and income from financial assets has become an important part of the operating income of enterprises, thereby influencing their innovation activities. This study constructs an econometric model using a total of 17855 firm-years panel data of non-financial listed companies in China A-shares from 2009 to 2019 as the research sample, and empirically analyzes the influence mechanism between financial asset allocation incentives and corporate financial risk and enterprise innovation through fixed-effects regressions. The results indicate that the incentive to hold financial assets and financial risk have a crowding-out effect on an enterprise' $s$ innovation activities. We also find that enterprises with different ownership types and technological levels respond differently when faced with an incentive to hold financial assets, which brings about heterogeneous effects on innovation outputs. Finally, this study proposes relevant policy recommendations at both the government and the enterprise levels to address the financialization of real enterprises and non-financial enterprises' deviation from their main business to the virtual economy.
\end{abstract}

Keywords: Holding financial assets, financial risk, innovation, crowding-out effect, heterogeneity. 


\section{Introduction}

According to new economic growth theory, technological progress and knowledge accumulation are the core drivers of economic development. China has entered a new economic normal and is now in a critical period of economic transformation and development, with economic growth gradually shifting from factor-driven to innovation-driven. Under this new normal of slowing economic growth, return on investment for financial and non-financial enterprises differs. Financial enterprises have maintained high returns on capital by virtue of their policy advantages, while real estate enterprises have experienced an unprecedented golden period of development on the back of the sustained growth in house prices in recent years. On the contrary, downward economic pressure has had a greater negative impact on the return on investment of non-financial enterprises, and a large number have started to deviate from their main business to the virtual economy represented by the financial and real estate industries, thus affecting financial enterprises (Wu and Wang, 2018).

The profit-seeking nature of capital has led to a shift away from the real economy toward capital and real estate markets in which capital turnover is faster, a phenomenon also known as "enterprise financialization" (Krippner, 2005; Orhangazi, 2008).The financialization of enterprises is manifested in two ways. First, from a behavioral perspective, the financialization of enterprises is a resource allocation method that favors capital operations, which is manifested in the use of enterprise assets for investment rather than traditional production and operation activities (Dai et al., 2018). Second, from a results perspective, the financialization of enterprises means that firms' profits are more often derived from investment and capital operations in non-production operations; in other words, enterprises are pursuing pure capital appreciation rather than operating profits (Cai and Ren, 2014). With the increasingly delicate relationship between the financial sector and real economy, the trend of financialization in the economy is accelerating and the accumulation of profits based on financial channels is gradually becoming the dominant mode of enterprise profitability (Zhang and Zhang, 2016). Xie et al. (2014) argue that when firms rely too heavily on the financial sector for their revenue streams, this inevitably changes managers' capital investment preferences (Xie et al., 2014); Orhangazi(2008), Seo et al.(2012), Akkemik \& Zen(2013), Tori, Onaran (2018) and other scholars pointed out that financial asset allocation would change the investment behavior of enterprises and inhibit their investment in physical capital to a certain extent by studying the financial asset allocation and investment behavior of enterprises in several countries(Orhangazi, 2008; Seo et al., 2012; Akkemik and Özen, 2014; Tori and Onaran, 2018).Hence, it is rational that long-cycle, high-risk (high-end) technological innovation activities are rejected by firms (Chen and Zhang, 2020; Brown and Petersen, 2011). The allocation of more capital to the financial sector has a significant substitution effect, subject to resource investment constraints. 
At the same time, from the risk control perspective, a firm's financing behavior is closely related to its risk derivation, and the allocation of financial assets introduces a wide range of capital market risks to the firm, increasing its overall financial risk. Therefore, when considering firms' allocation of financial assets, it is necessary to explore their financial risk. R\&D and innovation activities require more capital than fixed asset investments and face high adjustment costs in the event of disruption (Hall, 2002). Innovation activities are also risky and unstable and they result in intangible assets that are difficult to collateralize, meaning that firms are often constrained by the financing environment and have an incentive to smooth out $R \& D$ innovation (Brown and Petersen, 2011) .

Based on the foregoing analysis, in this study, we construct an econometric model and draw data from a sample of Chinese A-share non-financial non-real estate listed companies from 2009-2019 to empirically analyze the impact mechanism between the incentive to hold financial assets and enterprises' financial risk and innovation activities. The findings show that both the incentive to hold financial assets and an enterprise's financial risk have a crowding-out effect on innovation activities. Further, the ownership type and technological level of a firm have a moderating role in the above relationship. The crowding-out effect of the incentive to hold financial assets on innovation activities is more pronounced in non-state-owned enterprises (SOEs) and enterprises in low-tech industries. The impact of financial risk on innovation activities is stronger in non-SOEs and enterprises in high-tech industries.

This study makes two main intended contributions after it has been conducted. First, it examines the impact of the incentive to hold financial assets and financial risk on $R \& D$ innovation at the firm level and examines the heterogeneity of the impact mechanisms between types of firms. The literature on R\&D innovation from the perspective of enterprises' investment strategies or profitability models is scant, and only studies of working capital management and cash holdings exist. Second, this study measures the impact of firms' allocation of financial assets on their innovation activities at two levels (the incentive to hold financial assets and financial risk) and explains the impact of financial risk on innovation due to the allocation of financial assets. The existing literature usually examines the impact mechanism only at the level of the share of financial assets held or the profitability of those assets.

\section{Theoretical Background and Assumptions}

There are two motivations for firms to hold financial assets: one is to seek arbitrage by holding less liquid financial assets in pursuit of higher returns and the other is to hold more liquid financial assets to alleviate the financing constraints that arise when unexpected events arise. The impact of enterprise financialization on innovation investment differs for these motivations. Song and Yang (2015) find a 
U-shaped relationship between firms' performance and financial asset holdings but both high- and low-yielding firms reduce their innovation investment to some extent. According to Markowitz's portfolio theory, an increase in the allocation of financial assets under a fixed financing constraint reduces the funds for other activities, such as R\&D and innovation, resulting in firms having to put innovation plans on hold. Wang et al. (2017) argue that Chinese A-share non-financial listed companies tend to exhibit a negative correlation between enterprise financialization and innovation investment, which is greatly enhanced by their arbitrage motives. Liu et al. (2019), after dividing the allocation of financial assets into financial asset holding shares and financial channel profits, finds that although both crowd out firms' R\&D and innovation activities in the current period, the former helps drive firms' R\&D and innovation activities in future periods, while the latter has only a hindering effect on innovation investment in both the current and the future periods. Based on agency theory, when firms can rely on holding financial assets to make large profits, they are perceived as having a good business status and this reduces management's sense of crisis about the firm's operations, thus making managers less motivated to innovate points out that increased incentives for the allocation of financial assets enhances management's focus on the financial sector, leading to a short-sighted business strategy. If management is keen to make profits through financial channels, this inevitably diverts attention from the real economy, leading to a reduced focus on long-term enterprise development and innovation. Based on the above research, the following hypothesis is proposed:

H1: A higher incentive to hold financial assets has a greater inhibitory effect on innovation activities.

Financial risk refers to the difference between the actual earnings of an enterprise and its expectations due to various uncertainties in complex and changing internal and external environments. During a firm's development and operations, the consequences of its activities are reflected in its financial indicators; hence, the risk faced by the enterprise is ultimately expressed as financial risk. Financial products are also affected by policies and capital market fluctuations, which have a high degree of uncertainty and risk. This is likely to be transmitted to the enterprise, manifesting as a "risk contagion effect", and leads to relatively high financial risk. In the presence of financial risk, firms make investment decisions based on return on assets, and the increase in investment in financial assets is inevitably accompanied by a decrease in $R \& D$ and innovation activities.

At the same time, R\&D innovation activities are characterized by high investment, high uncertainty, and long cycles, and the financial stability of enterprises is crucial for their technological innovation activities. The funds for the R\&D expenditure of enterprises mainly come from two parts: internal cash flow from production and operations and the external financing environment brought about by the development of financial markets (Gorodnichenko and Schnitzer, 2011; Ju 
et al., 2013). Based on agency theory, as firms' financial risk increases, they become more cautious in their business activities, preferring projects with stable and lowrisk returns and thus scaling back innovative projects with long lead times, high risks, and slow capital turnover. Therefore, this study proposes the following hypothesis:

H2: Higher financial risk has a greater inhibitory effect on a firm's innovation activities.

As the impact of an enterprise's allocation of financial assets and financial risk on innovation investment can differ, it is necessary to distinguish firms according to their individual characteristics that have been shown to be the main factors affecting innovation activities (Wang, 2017). First, the different ownership types of enterprises may affect the relationship between the allocation of financial assets and their innovation activities. SOEs have more social responsibilities, such as stabilizing growth and preserving employment, which require them to have relatively fixed requirements for asset allocation and be less subject to external influences. Moreover, as SOEs can obtain lower-cost financing more easily than non-SOEs, they do not have a strong incentive to hold financial assets with larger returns. Hence, the relatively low financing cost leads the allocation of financial assets to have a small impact on enterprises' innovation investment. Based on the above analysis, this study proposes the following hypotheses:

H3-1: SOEs' incentive to hold financial assets has a smaller inhibitory effect on innovation activities than that of non-SOEs.

H3-2: The financial risk of SOEs has a less inhibitory effect on innovation activities than that of non-SOEs.

Second, the classification of firms into high-tech and low-tech firms to study their innovation activities allows for a more accurate analysis of their impact mechanisms. The innovation activities of enterprises are highly related to their technological level. As the innovation of high-tech industries is higher than that of low-tech industries, the enterprises have a good innovation foundation, and innovation activities are one of the main driving forces to support their development; Thus, an increase in financial asset allocation has less impact on their normal innovation activities. Although firms' allocation of financial assets aims to provide better funding sources for innovation, innovation activities have long cycles and high uncertainty, thus the increase in financial risk has a significant impact on them. However, low-tech industries, whose operations are more likely to be in traditional markets and whose innovation activities are less active and policy-driven than those of high-tech industries, are more likely to transfer limited resources from technology R\&D to the capital market under the market profit orientation. This reduces these enterprises' financing constraints, thus reducing long-cycle and high-uncertainty innovation activities. Based on the above analysis, the following hypotheses are proposed.

H4-1: The incentive to hold financial assets has a lower inhibitory effect on the 
innovation activities of high-tech firms than those of low-tech firms.

H4-2: Financial risk has a greater inhibitory effect on the innovation activities of high-tech firms than those of low-tech firms.

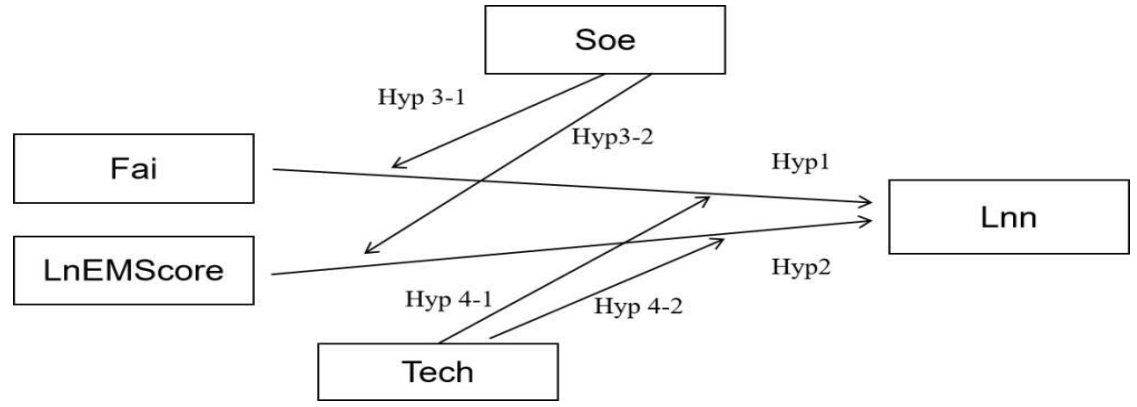

Fig. 1: Conceptual framework

\section{Research Method}

Drawing on the methodology of previous studies, this section provides an introduction to the research methodology of this paper. It mainly includes three parts: data source and sample establishment, definition and measurement of variables, and research model.

\subsection{Data Collection}

Given the implementation of new accounting standards in China in 2007, global financial crisis in 2008, and large and unstable changes in enterprises' financial indicators and allocation of financial assets, we sample listed companies from 2009-2019. Our data are obtained from the CSMAR database. To reduce the influence of outliers, the variables are winsorized at the upper and lower $1 \%$ levels. Further, the continuous variables are shown as logarithms to reduce the interference of heteroscedasticity.

\subsection{Definition of the Variables}

\subsubsection{Dependent Variable}

The dependent variable is an enterprise's R\&D innovation, denoted as Lnn, which is measured by the proportion of net intangible assets as a percentage of total assets following $\mathrm{Ju}$ et al. (2013), Xie et al. (2014) and Liu (2017) (Liu et al., 2019). Research on firms' $R \& D$ innovation has also used $R \& D$ expenditure and the number of patents to measure $R \& D$. This study adopts the proportion of intangible assets for three reasons. First, they are closely related to an enterprise's R\&D innovation, which is the result of its innovation investment and can therefore reflect its R\&D innovation outcomes comprehensively. Second, R\&D expenditure does not fully reflect enterprises' technological development because it excludes their patents, copyrights, and trademarks. Similarly, the number of patents can reflect enterprises' 
technological innovation, but does not fully reflect their innovation activities. Finally, the disclosure of $R \& D$ and number of patents by Chinese non-financial listed companies is not comprehensive, with many samples missing.

\subsubsection{Independent Variable}

The incentive to hold financial assets refers to a firm's earnings through the financial asset channel. This study draws on those of Cai et al. (2018) and Qi and Zhang (2018) to measure the incentive of firms to hold financial assets using the ratio of financial asset profitability to operating profit (Cai et al., 2018; Liu, 2017). The profit on financial assets mainly includes interest income, the gain in fair value change, investment income, investment income in subsidiaries and joint ventures, foreign exchange gain, and other investment income related to the enterprise's financial assets. Thus, examining the share of profit from financial assets in all firms' activities can better explain their incentive to make market-based financial investments to earn profits. Given that some samples have negative operating profits, this study draws on the approach of Zhang and Zhang (2016) to standardize the absolute value of operating profits by dividing the balance of financial channel profits minus operating profits by the absolute value of operating profits (Zhang and Zhang, 2016).

To measure an enterprise's financial risk, Altman (1968) lists 22 variables that may affect financial position in terms of liquidity, profitability, leverage, and solvency and obtains a Z-score model that includes five variables to measure financial position (Qi and Zhang, 2018). This model is widely accepted internationally as an indicator of financial risk. The original Z-score model was only applicable to ranking the financial performance of manufacturing companies. Hence, in 1996, Altman expanded the Z-score model by proposing the emerging market score (EMS) model for risk scoring, mainly for emerging market companies. The formula is as follows:

$$
\text { EMScore }=6.56 \times 1+3.26 \times 2+6.72 \times 3+1.05 \times 4+3.25
$$

where $\mathrm{X} 1$ is working capital/total assets, $\mathrm{X} 2$ is retained earnings/total assets, $\mathrm{X} 3$ is operating income/total assets, and X4 is equity book value/total liabilities. The financial risk rating criteria are set by the equivalent of the U.S. debt rating; when $\mathrm{Z}$ is greater than 5.85, the company is in a safe financial position; when $\mathrm{Z}$ is greater than 4.15 , the company is in a gray area; when $\mathrm{Z}$ is $1.75-4.15$, the company is in a crisis area; and when $\mathrm{Z}$ is less than 1.75 , the company is in a distressed financial position. Altman (2005) confirms that the model has been successfully applied in Mexico, Brazil, and Argentina, among other countries (Altman, 1968). In China, a representative emerging market country, Altman (2005) and Zhang (2017) apply this model to study the financial risk of Chinese listed companies and verify that it is applicable in this context (Altman, 2005; Zhang, 2017). Therefore, this study uses the EMS model to measure the financial risk of listed companies. 


\subsubsection{Moderating Variables}

In this study, firms' ownership types and technological levels are selected as the moderating variables. A firm's ownership type (Soe), compiled from information in the CSMAR database, is a dummy variable coded 1 when the enterprise is an SOE and 0 otherwise. The definition of a high-tech industry was first provided by the Organisation for Economic Co-operation and Development (OECD) in 1986, and the main criterion used to define a high-tech industry was the proportion of R\&D expenditure to output. Later, to make the study of high-tech industries internationally comparable, the OECD divided high-tech industries into six major industries: aerospace manufacturing, pharmaceutical manufacturing, computer and office equipment manufacturing, electrical machinery manufacturing, scientific instruments and meters manufacturing, and electronic and communication equipment manufacturing. To accurately reflect the development of industries, China revised the original classification and issued the Classification of High-Tech Industries (Manufacturing) (2017), while adding and updating information on the chemical manufacturing industry in the China High-Tech Industry Statistical Yearbook. The proportion of tertiary industries in the national economy is gradually increasing, and service industries such as electronic information and professional and technical services have been developing rapidly in recent years, thereby changing the production and lifestyle of enterprises and residents. According to the State Council Classification of High Technology Industries (Service Industry) (2018), the service industry is a collection of service activities using high-tech means including information services, e-commerce services, inspection and testing services, high-tech services of professionals and the technical service industry, R\&D and design services, science and technology achievement transformation services, intellectual property and related legal services, environmental monitoring and governance services, and other services. To create the industry classification, this study draws on Liu et al. (2018) by using the listed company (2012 version) industry classification guidelines to screen 13 industries as high-tech industries (coded 1) and low-tech industries (coded 0) (Wang et al., 2017).

\subsubsection{Control Variables}

Following the literature, this study adds a series of variables that may affect a firm's innovation activities: the year of establishment (Age), asset/liability ratio (Lev), equity concentration $(C D)$, largest shareholder concentration $(S D)$, total assets (Asset), net profit growth $(P-G)$, and capital intensity $(C D)$, defined as the ratio of total assets to operating income. Further, because there are great differences in technological innovation among industries, we introduce industry fixed effects. Following the industry classification guidelines of listed companies (2012), listed companies are divided into 19 categories and 90 industry design variables. If the enterprise belongs to this industry, the value is 1 ; otherwise, it is 0 . Finally, as the macro-level environment and policies change, the level of technological innovation 
may vary considerably each year. Hence, we introduce time fixed effects, coded 1 if the enterprise is operating in that year and 0 otherwise.

Table 1: Variable Names and Definitions

\begin{tabular}{|c|c|c|c|}
\hline & $\begin{array}{l}\text { Variable } \\
\text { symbol }\end{array}$ & Variable name & Variable definition \\
\hline $\begin{array}{l}\text { Depend } \\
\text { ent } \\
\text { variable }\end{array}$ & Lnn & $\begin{array}{l}\text { Percentage of } \\
\text { intangible } \\
\text { assets }\end{array}$ & Intangible assets as a percentage of total assets \\
\hline \multirow[t]{2}{*}{$\begin{array}{l}\text { Indepen } \\
\text { dent } \\
\text { variable }\end{array}$} & Fai & $\begin{array}{l}\text { Incentive to } \\
\text { hold financial } \\
\text { assets }\end{array}$ & $\begin{array}{c}\text { (Gain on changes in fair value }+ \text { investment } \\
\text { income }+ \text { investment income in subsidiaries and } \\
\text { joint ventures }+ \text { foreign exchange gain }+ \text { interest } \\
\text { income - } \\
\text { operating profit)/| Operating profit } \mid\end{array}$ \\
\hline & $\begin{array}{l}\text { LnEMSc } \\
\text { ore }\end{array}$ & $\begin{array}{l}\text { Financial } \\
\text { risk }\end{array}$ & $\begin{array}{c}\text { Using Altman's (2005) EMS model to measure } \\
\text { (Altman, 1968) } \\
\text { business risk }\end{array}$ \\
\hline \multirow{2}{*}{$\begin{array}{l}\text { Moderat } \\
\text { ing } \\
\text { variable } \\
\text { s }\end{array}$} & Soe & $\begin{array}{c}\text { A firm's } \\
\text { ownership type }\end{array}$ & $\begin{array}{c}1=\text { SOEs, } 0=\text { non-state-owned } \\
\text { enterprises }\end{array}$ \\
\hline & Tech & $\begin{array}{c}\text { A firm's } \\
\text { technological } \\
\text { level }\end{array}$ & $1=$ high-tech enterprise, $0=$ low-tech enterprise \\
\hline \multirow{7}{*}{$\begin{array}{l}\text { Control } \\
\text { variable } \\
\mathrm{s}\end{array}$} & $\begin{array}{l}\text { Salesgro } \\
\text { wth }\end{array}$ & $\begin{array}{l}\text { Business growth } \\
(\%)\end{array}$ & $\begin{array}{l}\text { Revenue from main operations for the period/ } \\
\text { Revenue from main operations for the previous } \\
\text { period - } 1\end{array}$ \\
\hline & Age & $\begin{array}{l}\text { Year of } \\
\text { establishment of } \\
\text { the business }\end{array}$ & (Year of study - year of launch) +1 \\
\hline & Lev & Gearing ratio & Total liabilities/total assets \\
\hline & $S D$ & $\begin{array}{l}\text { Concentration } \\
\text { of } \\
\text { shareholding }\end{array}$ & $\begin{array}{c}\text { Percentage of shareholding of the largest } \\
\text { shareholder }\end{array}$ \\
\hline & Lnasset & Total assets & $\begin{array}{l}\text { Total assets disclosed in the current } \\
\text { period financial statements }\end{array}$ \\
\hline & $P-G$ & $\begin{array}{l}\text { Net profit } \\
\text { growth }\end{array}$ & $\begin{array}{l}\text { (Net profit for the period - net profit for the } \\
\text { previous period)/net profit for the previous } \\
\text { period } * 100 \%\end{array}$ \\
\hline & $C D$ & Capital intensity & Ratio of total assets to operating revenue \\
\hline
\end{tabular}

\subsection{Research Model}

To analyze the impact of firms' incentive to hold financial assets and financial risk 
on their innovation activities, drawing on Cai et al. (2018) (Cai et al., 2018). This study sets the following panel econometric model:

$$
\begin{aligned}
& \mathrm{Lnn}_{\mathrm{it}}=\alpha_{0}+\alpha_{1} \mathrm{Fai}_{-1}+\Sigma \text { Control }_{\mathrm{it}}+\mu_{\mathrm{i}}+\gamma_{\mathrm{t}}+\varepsilon_{\mathrm{it}} \\
& \operatorname{Lnn}_{i t}=\alpha_{3}+\alpha_{4} \text { LnEMScore }+\Sigma \text { Control }_{\mathrm{it}}+\mu_{\mathrm{i}}+\gamma_{\mathrm{t}}+\varepsilon_{\mathrm{it}}
\end{aligned}
$$

where the subscripts $\mathrm{i}$ and $\mathrm{t}$ denote the enterprise and period, respectively; Lnn denotes innovation activities; Fai denotes the incentive to hold financial assets, which is treated with a one-period lag (Fai-1) to avoid endogeneity and reverse causality problems and consider the lagged effect of earnings on innovation activity; and EMScore denotes the financial risk of the enterprise. Control denotes the series of control variables affecting innovation including a firm's year of establishment (Age), gearing ratio $(L e v)$, equity concentration $(C D)$, concentration of the largest shareholder $(S D)$, total assets (Asset), net profit growth rate $(P-G)$, and capital intensity $(C D)$. In addition, to mitigate the effects of individual heterogeneity and period characteristics on firms' $R \& D$ and innovation activities, individual fixed effects $\mu \mathrm{i}$ and time fixed effects $\gamma \mathrm{t}$ are considered to eliminate the effects of timeinvariant firm characteristics and macroeconomic environments.

To further verify the roles of a firm's ownership type and technological level in the crowding-out effect of the allocation of financial assets on innovation activities, the interaction term with the firm's incentive to hold financial assets is added into the benchmark model:

$$
\begin{aligned}
& \operatorname{Lnn}_{\text {it }}=\beta_{0}+\beta_{1} \text { Fai }_{-1}+\beta_{2} \text { Soe }+\Sigma \text { Control }_{\mathrm{it}}+\mu_{\mathrm{i}}+\gamma_{\mathrm{t}}+\varepsilon_{\mathrm{it}} \\
& \mathrm{Lnn}_{\mathrm{it}}=\beta_{0}+\beta_{1} \mathrm{Fai}_{-1}+\beta_{2} \text { Soe }+\beta_{3} \mathrm{Fai}_{-1} * \text { Soe }+\Sigma \text { Control }_{\mathrm{it}}+\mu_{\mathrm{i}}+\gamma_{\mathrm{t}}+\varepsilon_{\mathrm{it}} \\
& \operatorname{Lnn}_{\mathrm{it}}=\theta_{0}+\theta_{1} \text { LnEMScore } \theta_{2} \text { Soe }+\Sigma \text { Control }_{\mathrm{it}}+\mu_{\mathrm{i}}+\gamma_{\mathrm{t}}+\varepsilon_{\mathrm{it}} \\
& \operatorname{Lnn}_{\mathrm{it}}=\theta_{0}+\theta_{1} \text { LnEMScore }+\theta_{2} \text { Soe }+\theta_{3} \text { LnEMScore }^{*} \text { Soe }+\Sigma \text { Control }_{\mathrm{it}}+\mu_{\mathrm{i}}+\gamma_{\mathrm{t}}+\varepsilon_{\mathrm{it}}
\end{aligned}
$$

Model (3) adds the firm's ownership type variable (Soe) into Model (1) and Model (4) adds the interaction term between ownership type and the incentive to hold financial assets into Model (3). When Soe takes the value of 1 (0), it indicates SOEs (non-SOEs). If the coefficient $\beta 3$ of Fai- $1 *$ Soe in Model (4) is positive and significant, it means that the incentive to hold financial assets has a weaker crowding-out effect on innovation activities in SOEs than in non-SOEs. If it is negative, it indicates that the incentive to hold financial assets has a greater crowding-out effect on innovation activities in SOEs. Similarly, Model (5) adds Soe into Model (2) and Model (6) adds the interaction term of ownership type and financial risk into Model (5). If the coefficient $\theta 3$ of LnEMScore*Soe in Model (6) 
is positive and significant, it indicates that financial risk has a weaker effect on innovation activities in SOEs than in non-SOEs. If the coefficient of $\theta 3$ for LnEMScore*Soe in Model (6) is positive and significant, it indicates that financial risk has a weaker crowding-out effect on innovation in SOEs than in non-SOEs, whereas if it is negative, it indicates that financial risk has a greater crowding-out effect on innovation activities in SOEs.

To further verify the moderating role of firms with different technological levels in the crowding-out effect of the incentive to hold financial assets and financial risk on innovation activities, the following model is constructed by adding the interaction term with financial risk into the benchmark model:

$$
\begin{aligned}
& \operatorname{Lnn}_{\mathrm{it}}=\varphi_{1}+\varphi_{2} \text { Fai }_{-1}+\varphi_{3} \text { Tech }+\Sigma \text { Control }_{\mathrm{it}}+\mu_{\mathrm{i}}+\gamma_{\mathrm{t}}+\varepsilon_{\mathrm{it}} \\
& \mathrm{Lnn}_{\mathrm{it}}=\varphi_{0}+\varphi_{1} \text { Fai }_{-1}+\varphi_{2} \text { Tech }+\varphi_{3} \text { Fai }_{-1} * \text { Tech }+\Sigma \text { Control }_{\mathrm{it}}+\mu_{\mathrm{i}}+\gamma_{\mathrm{t}}+\varepsilon_{\mathrm{it}} \\
& \mathrm{Lnn}_{\mathrm{it}}=\lambda_{0}+\lambda_{1} \text { LnEMScore }+\lambda_{2} \text { Tech }+\Sigma \text { Control }_{\mathrm{it}}+\mu_{\mathrm{i}}+\gamma_{\mathrm{t}}+\varepsilon_{\mathrm{it}} \\
& \mathrm{Lnn}_{\mathrm{it}}=\lambda_{0}+\lambda_{1} \text { LnEMScore }+\lambda_{2} \text { Tech }+\lambda_{3} \text { LnEMScore } * \text { Tech }+\Sigma \text { Control }_{\mathrm{it}}+\mu_{\mathrm{i}}+\gamma_{\mathrm{t}}+\varepsilon_{\mathrm{it}}
\end{aligned}
$$

Models (7) and (8) are based on Model (1) with the addition of the technological level variable (Tech) and interaction term between the incentive to hold financial assets and technological level, respectively. When Tech takes a value of 1 , it indicates a high-tech firm and 0 otherwise. If the coefficient $\varphi 3$ of Fai-1*Tech in Model (8) is positive and significant, it indicates that a higher incentive to hold financial assets in high-tech firms has less crowding-out effect on innovation activities than in low-tech firms. Similarly, Models (9) and (10) are based on Model (2) with the addition of Tech and the interaction term of financial risk and technological level, respectively. If the coefficient $\lambda 3$ of LnEMScore ${ }^{*}$ Tech in Model (10) is negative and significant, it indicates that higher financial risk in high-tech firms has a greater crowding-out effect on innovation activities than in low-tech enterprises.

\section{Empirical Results}

Based on the above assumptions and the establishment of the model, this paper obtains the following empirical analysis results through regression analysis of sample data.

\subsection{Descriptive Statistics}

Table 2 presents the mean, median, standard deviation, minimum, and maximum values of the variables included in the analysis and confirms that there are no outliers or major violations of the regression hypothesis. Among them, the natural 
logarithm of the proportion of intangible assets, which measures the technological innovation of enterprises, has a mean value of -3.520 , a standard deviation of 1.135, a maximum value of -1.117 , and a minimum value of -8.091 , which shows that there are differences in the proportion of intangible assets among listed companies, explaining the differences in innovation activities to some extent. The incentive to hold financial assets ( Fai) has a maximum value of 5.194, a minimum value of 3.831 , and a mean value of -0.757 . A mean above -1 indicates that the contribution of financial channel profitability to enterprise profits is positive (Liu et al. 2018). The natural logarithm of financial risk has a maximum value of 3.539, a minimum value of 1.298 , and a mean value of 2.443 .

Table 2: Descriptive statistics

\begin{tabular}{|c|c|c|c|c|c|c|}
\hline Variable & $\mathbf{N}$ & Mean & Median & SD & Min & Max \\
\hline Lnn & 17855 & -3.520 & -3.361 & 1.135 & -8.091 & -1.117 \\
\hline Fai & 17855 & -0.757 & -0.973 & 0.947 & -3.831 & 5.194 \\
\hline LnEMScore & 17855 & 2.443 & 2.453 & 0.415 & 1.298 & 3.539 \\
\hline Lnasset & 17855 & 22.14 & 21.97 & 1.301 & 19.77 & 26.16 \\
\hline CD & 17855 & 2.244 & 1.769 & 1.713 & 0.383 & 11.12 \\
\hline Lev & 17855 & 0.419 & 0.412 & 0.204 & 0.0500 & 0.873 \\
\hline SD & 17855 & 35.21 & 33.32 & 15.07 & 8.448 & 74.98 \\
\hline PG & 17855 & 3.283 & -0.369 & 15.97 & -24.66 & 117.6 \\
\hline Salesgrowth & 17855 & 8.088 & 0.186 & 30.95 & -0.992 & 241.7 \\
\hline Age & 17855 & 16.28 & 16.17 & 5.735 & 3.420 & 30.83 \\
\hline
\end{tabular}

Table 3 shows the Pearson correlation coefficients of the main variables. The correlation coefficients of the incentive to hold financial assets (Fai) and financial risk (LnEMScore) with innovation activities (Lnn) are -0.048 and -0.114 , respectively (significant at the $1 \%$ level), which initially supports the previous hypothesis.

Table 3: Correlation matrix

\begin{tabular}{|c|c|c|c|c|c|c|c|c|c|c|c|}
\hline & Variable & (1) & (2) & (3) & (4) & (5) & (6) & (7) & (8) & (9) & (10) \\
\hline 1 & Lnn & 1 & & & & & & & & & \\
\hline 2 & $\mathrm{Fai}$ & $-0.048^{* * * *}$ & 1 & & & & & & & & \\
\hline 3 & LnEMScore & $-0.114^{* * *}$ & $-0.091^{* * *}$ & 1 & & & & & & & \\
\hline 4 & Lnasset & $0.021^{* * * *}$ & $0.060 * * *$ & $-0.334 * * *$ & 1 & & & & & & \\
\hline 5 & $C D$ & $-0.043^{* * *}$ & $0.124^{* * * *}$ & $-0.331^{* * * *}$ & $-0.019^{* * *}$ & 1 & & & & & \\
\hline 6 & Lev & -0.003 & $0.045^{* * * *}$ & $-0.634 * * *$ & $0.502^{\text {**** }}$ & $-0.152^{* * * *}$ & 1 & & & & \\
\hline 7 & $S D$ & $-0.013^{*}$ & $-0.030^{* * *}$ & $0.064^{* * *}$ & $0.165^{* * *}$ & $-0.093^{* * * *}$ & $0.043^{* * *}$ & 1 & & & \\
\hline 8 & $P G$ & 0.00700 & $0.032^{* * * *}$ & 0.001 & $-0.151 * * *$ & $0.036^{* * * *}$ & $-0.041^{* * * *}$ & $-0.034 * * *$ & 1 & & \\
\hline 9 & Salesgrowth & $-0.013 *$ & $0.017 * *$ & $-0.024 * * *$ & $0.426^{* * * *}$ & $-0.119 * * *$ & $0.219^{* * *}$ & $0.125^{* * *}$ & $-0.053^{* * * *}$ & 1 & \\
\hline
\end{tabular}


\begin{tabular}{|c|c|c|c|c|c|c|c|c|c|c|c|}
\hline 10 & Age & $-0.026^{* * *}$ & $0.106^{* * *}$ & $-0.172^{* * *}$ & $0.198^{* * *}$ & $0.048^{* * *}$ & $0.175^{* * *}$ & $-0.129^{* * *}$ & -0.004 & 0.007 & 1 \\
\hline
\end{tabular}

$\mathrm{N}=17855 ; * * * \mathrm{p}<0.01, * * \mathrm{p}<0.05, * \mathrm{p}<0.1$

\subsection{Results of the Regression Analysis}

\subsubsection{Incentive to Hold Financial Assets, Financial Risk, and Innovation Activities}

Table 4 shows the results of the roles of the incentive to hold financial assets, financial risk, and innovation activities. According to the results of the Hausman test, the p-value is less than 0.05 . Hence, we select the fixed effect regression. This study adopts a recursive regression treatment, first considering the univariate regression results controlling for the time and industry fixed effects and then incorporating the relevant set of control variables to test whether the empirical results are robust and reliable. As shown in Model (1), the coefficient of the incentive to hold financial assets is -0.02 , which is significant at the $5 \%$ level. This indicates that such an incentive has a significant inhibitory effect on innovation activities, thus supporting Hypothesis 1 . This is because a higher incentive for an enterprise to hold financial assets, when it relies on holding financial assets to gain lucrative profits, provides it with a perception of a good business status and reduces management's sense of crisis about its operations, thus weakening the incentive to innovate. Owing to the short-sightedness of management, this inevitably reduces investment in real economic activities and even innovation activities and can force the firm to choose between them. In turbulent economic environments and sluggish international markets, the profitability of the real economy faces significant constraints, and companies have to invest their resources in the financial sector to maintain their profitability in exchange for high returns.

Model (2) presents the regression results of financial risk and innovation activities. The coefficient of financial risk in Model (2) is -0.722 , which is significant at the $1 \%$ level, indicating that an increase in financial risk significantly reduces the number of innovation activities, which supports Hypothesis 2. Enterprises' R\&D and innovation activities are inherently risky and uncertain, and most lead to intangible assets that cannot be easily realized by collateral. According to agency theory, when the financial risk of an enterprise increases, managers become more cautious in their business activities, preferring projects with stable and low-risk returns, and curtail innovation projects with long cycles, high risks, and slow capital turnover. Therefore, the financial risk of a firm has a significant effect on its level of innovation.

\subsubsection{Tesring the Mechanism of the Moderating Effects}

From the previous estimation results for the full sample, we see that both the incentive to hold financial assets and financial risk have crowding-out effects on innovation activities. However, it is not possible to judge whether the effects differ 
for enterprises with different characteristics related to the firm's innovation activities. Hence, the interaction term of the dummy variables with the lagged term of the allocation of financial assets is introduced into the regression model to verify the moderating role of a firm's ownership type and technological level on the incentive to hold financial assets, financial risk, and innovation activities.

Table 4: Incentive to Hold Financial Assets, Financial Risk, and Innovation Activities:

Fixed Effects Regression

\begin{tabular}{|c|c|c|}
\hline & Model (1) & Model (2) \\
\hline Variable & Lnn & Lnn \\
\hline \multirow[t]{2}{*}{ Fai-1 } & $-0.020 * *$ & \\
\hline & $(-2.34)$ & \\
\hline \multirow[t]{2}{*}{ LnEMScore } & & $-0.722 * * *$ \\
\hline & & $(-22.87)$ \\
\hline \multirow[t]{2}{*}{ Lnasset } & $0.029 * * *$ & $0.037 * * *$ \\
\hline & $(3.28)$ & $(4.45)$ \\
\hline \multirow[t]{2}{*}{$C D$} & $-0.012 * *$ & $-0.078 * * *$ \\
\hline & $(-2.31)$ & $(-13.26)$ \\
\hline \multirow[t]{2}{*}{ Lev } & $0.136^{* * *}$ & $-0.839 * * *$ \\
\hline & $(2.69)$ & $(-12.48)$ \\
\hline \multirow[t]{2}{*}{$S D$} & $-0.003 * * *$ & $-0.002 * * *$ \\
\hline & $(-5.02)$ & $(-3.34)$ \\
\hline \multirow[t]{2}{*}{$P G$} & $0.001 * *$ & $0.001 *$ \\
\hline & $(1.99)$ & $(1.83)$ \\
\hline \multirow[t]{2}{*}{ Salesgrowth } & -0.000 & $0.001 * *$ \\
\hline & $(-0.36)$ & $(1.99)$ \\
\hline \multirow[t]{2}{*}{ Age } & $-0.012 * * *$ & $-0.010 * * *$ \\
\hline & $(-7.40)$ & $(-6.23)$ \\
\hline \multirow[t]{2}{*}{ Constant } & $-3.875 * * *$ & $-1.827 * * *$ \\
\hline & $(-20.64)$ & $(-9.17)$ \\
\hline Year Fx & yes & yes \\
\hline Industry Fx & yes & yes \\
\hline $\mathrm{N}$ & 17,855 & 17,855 \\
\hline R-squared & 0.204 & 0.224 \\
\hline Adjusted R-squared & 0.199 & 0.220 \\
\hline
\end{tabular}

$* * * \mathrm{p}<0.01, * * \mathrm{p}<0.05, * \mathrm{p}<0.1$

\subsubsection{Moderating Effect of a Firm's Ownership Type Combined With the Incentive to Hold Financial Assets and Financial Risk}

Table 5 presents the regression results of the interaction term between a firm's ownership type and the incentive to hold financial assets and financial risk. The 
coefficient of the lagged term of the incentive to hold financial assets in Model (4) is -0.071 , the coefficient of ownership type is 0.044 , and the coefficient of the interaction term of the incentive to hold financial assets and ownership type (Fai$1 *$ Soe) is 0.05 , all significant at the $1 \%$ level. Compared with Model (3), the Rsquared and adjusted R-squared of Model (4) increase, which shows that ownership type moderates the crowding-out effect of the incentive to hold financial assets on firms' innovation and that the crowding-out effect of the incentive to hold financial assets on innovation activities is weaker in SOEs than in non-SOEs, supporting Hypothesis 3-1. In Model (6), the interaction term between financial risk and ownership type (LnEMScore*Soe) is added from Model (5). The coefficient of the interaction term is 0.08 , significant at the $10 \%$ level. Compared with Model (5), the R-squared and adjusted R-squared increase, which shows that ownership type moderates the inhibitory effect of financial risk on innovation activities and that the crowding-out effect of the incentive to hold financial assets on innovation activities is smaller in SOEs than in non-SOEs, supporting Hypothesis 3-2.

Table 5: Interaction effect of a firm's ownership type combined with the incentive to hold financial assets and financial risk

\begin{tabular}{|c|c|c|c|c|}
\hline Variable & Model (3) & Model (4) & Model (5) & Model (6) \\
\hline & Lnn & Lnn & Lnn & Lnn \\
\hline \multirow[t]{2}{*}{ Fai-1 } & $-0.063 * * *$ & $-0.071 * * *$ & & \\
\hline & $(-4.29)$ & $(-4.64)$ & & \\
\hline \multirow[t]{2}{*}{ LnEMScore } & & & $-0.711 * * *$ & $-0.709 * * *$ \\
\hline & & & $(-22.81)$ & $(-22.75)$ \\
\hline \multirow[t]{2}{*}{$S O E$} & $0.046 * *$ & $0.044 * *$ & $0.060 * * *$ & $0.063 * * *$ \\
\hline & $(2.52)$ & $(2.43)$ & $(3.02)$ & $(3.16)$ \\
\hline \multirow[t]{2}{*}{ Fai-1*Soe } & & $0.050 *$ & & \\
\hline & & $(1.77)$ & & \\
\hline \multirow[t]{2}{*}{ LnEMScore*Soe } & & & & $0.080^{*}$ \\
\hline & & & & $(1.94)$ \\
\hline \multirow[t]{2}{*}{ Lnasset } & 0.017 ** & $0.018 * *$ & $0.031 * * *$ & $0.031 * * *$ \\
\hline & $(1.98)$ & $(2.02)$ & (3.64) & (3.64) \\
\hline \multirow[t]{2}{*}{$C D$} & 0.007 & 0.007 & $-0.073 * * *$ & $-0.072 * * *$ \\
\hline & $(1.11)$ & $(1.15)$ & $(-13.30)$ & $(-13.18)$ \\
\hline \multirow[t]{2}{*}{ Lev } & $0.106^{* *}$ & $0.111 * *$ & $-0.840 * * *$ & $-0.847 * * *$ \\
\hline & $(2.31)$ & $(2.42)$ & $(-12.59)$ & $(-12.69)$ \\
\hline \multirow[t]{2}{*}{$S D$} & $-0.002 * * *$ & $-0.002 * * *$ & $-0.002 * * *$ & $-0.002 * * *$ \\
\hline & $(-4.65)$ & $(-4.67)$ & $(-3.75)$ & $(-3.72)$ \\
\hline \multirow[t]{2}{*}{$P G$} & $0.002 *$ & $0.002 * *$ & $0.001 *$ & $0.001 *$ \\
\hline & $(1.95)$ & $(1.96)$ & $(1.68)$ & $(1.69)$ \\
\hline Salesgrowth & $-0.001 *$ & $-0.001 *$ & $0.001 *$ & $0.001 *$ \\
\hline
\end{tabular}




\begin{tabular}{|c|c|c|c|c|}
\hline & $(-1.90)$ & $(-1.89)$ & $(1.91)$ & $(1.92)$ \\
\hline Age & $-0.011 * * *$ & $-0.011 * * *$ & $-0.011 * * *$ & $-0.011 * * *$ \\
\hline & $(-7.04)$ & $(-7.01)$ & $(-6.72)$ & $(-6.75)$ \\
\hline Constant & $-3.380 * * *$ & $-3.395 * * *$ & $-1.448 * * *$ & $-1.447 * * *$ \\
\hline & $(-15.58)$ & $(-15.63)$ & $(-6.17)$ & $(-6.17)$ \\
\hline Year Fx & yes & yes & yes & yes \\
\hline Industry Fx & yes & yes & yes & yes \\
\hline N & 17855 & 17855 & 17,855 & 17,855 \\
\hline R-squared & 0.1971 & 0.1972 & 0.2242 & 0.2244 \\
\hline $\begin{array}{c}\text { Adjusted R- } \\
\text { squared }\end{array}$ & 0.1921 & 0.1922 & 0.2200 & 0.2201 \\
\hline
\end{tabular}

$* * * \mathrm{p}<0.01, * * \mathrm{p}<0.05, * \mathrm{p}<0.1 ;$ t-statistics in parentheses

\subsubsection{Moderating Effect of a Firm's Technological Level Combined With the Incentive to Hold Financial Assets anf Financial Risk}

Table 6 presents the regression results of the interaction term of a firm's technological level with the incentive to hold financial assets and financial risk. Models (7) and (8) report the regressions of the interaction term for technological level with the lagged term of the incentive to hold financial assets. In Model (8), the coefficient of the lagged term of the incentive to hold financial assets is -0.103 and that of the interaction term of technological level with the lagged term of the incentive to hold financial assets $(\mathrm{Fai}-1 * \mathrm{Tech})$ is 0.123 , both are significant at the $1 \%$ level. These are higher than those of Model (7) with significantly higher Rsquared and adjusted R-squared values. Hence, a firm's technological level has a stronger moderating effect in the incentive to hold financial assets on innovation activities and the crowding-out effect of the incentive to hold financial assets on innovation activities is smaller in enterprises in high-tech industries than in low-tech ones, supporting Hypothesis 4-1. Based on Model (9), Model (10) adds the interaction term (LnEMScore*Tech) of financial risk and technological level, the coefficient of which is -0.157 , significant at the $1 \%$ level. Compared with Model (9), the R-squared and adjusted R-squared values are significantly higher, showing that a firm's technological level plays a significant role in the impact of financial risk on innovation activities.

\section{Conclusion and Suggestion}

\subsection{Conclusion}

Along with the trend toward the financialization of the economy, the allocation of financial assets by non-financial enterprises is rapidly increasing, meaning that the investment patterns of enterprises and consequent changes in profitability models will have a far-reaching impact on enterprises' R\&D innovation (Reddy and 
Chowdary, 2016; Reddy et al., 2017). In recent years, the investment rate of nonfinancial enterprises in China has been declining, while their participation in the capital market has gradually increased (Zhao et al., 2021). This study examines the impact of the allocation of financial assets on non-financial enterprises' innovation activities. The empirical results show that the incentive to hold financial assets has a significant crowding-out effect on innovation activities and that financial risk hampers innovation. This paper argues that the ability of enterprises to obtain higher incentives through financial assets will make management feel less crisis, perceive that the enterprise is in good business condition, and reduce the incentive to innovate. Also, based on agency theory and the profit-seeking nature of capital, due to the high risk, high uncertainty and long payback period of innovation activities, management is bound to reduce their investment in real business activities and innovation activities and turn to the capital market due to their short-sighted potential, thus presenting the inhibitory effect of financial asset allocation incentives on corporate innovation activities. Moreover, in addition to the high risk of innovation activities themselves, their results are mostly in the form of intangible assets that cannot be easily encumbered and realized. When the financial risk of enterprises increases, the management will be more cautious about business activities and prefer to invest in less innovative projects with stable and less risky returns, so the increase of the financial risk of enterprises will inhibit the innovative activities of enterprises.

Further, we find a moderating effect of a firm's ownership type and technological level in the above relationship. First, when classified by ownership type, the crowding-out effect of the incentive to hold financial assets and financial risk on innovation activities is relatively weak in SOEs; however, the crowding-out effect of the incentive to hold financial assets and financial risk on innovation activities is weaker in non-SOEs than in SOEs. In non-SOEs, the crowding-out effect of the incentive to hold financial assets and financial risk on innovation activities is greater.

This study argues that SOEs, which receive state and government subsidies, shoulder certain social responsibilities and do not always aim to maximize firm value; hence, they are constrained from participating in financing and investment projects and more risk averse than non-SOEs. At the same time, SOEs face fewer financing constraints because of the support of the state and do not need to take excessive risks to hold financial assets to obtain financial flows in the same economic environment, which has less impact on their innovation activities. On the contrary, non-SOEs face greater financing constraints during economic downturns. Therefore, when the returns from the allocation of financial assets are higher than those from the real economy, non-SOEs have a stronger incentive to hold financial assets, thus reducing their real economic and innovation activities. 
Table 6: Interaction Effect of Enterprises' Technological Level Combined with the Incentive to Hold Financial Assets and Financial Risk

\begin{tabular}{|c|c|c|c|c|}
\hline \multirow[t]{2}{*}{ Variable } & Model (7) & Model (8) & Model (9) & Model (10) \\
\hline & Lnn & Lnn & Lnn & Lnn \\
\hline \multirow[t]{2}{*}{ Fai-1 } & $-0.060 * * *$ & $-0.103 * * *$ & & \\
\hline & $(-4.10)$ & $(-5.74)$ & & \\
\hline \multirow[t]{2}{*}{ LnEMScore } & & & $-0.711 * * *$ & $-0.649 * * *$ \\
\hline & & & $(-22.82)$ & $(-18.49)$ \\
\hline \multirow[t]{2}{*}{ Tech } & 0.098 & 0.209 & 0.140 & $0.476 * * *$ \\
\hline & $(0.67)$ & $(1.40)$ & $(0.87)$ & $(2.62)$ \\
\hline \multirow[t]{2}{*}{ Fai-1*Tech } & & $0.123 * * *$ & & \\
\hline & & $(4.12)$ & & \\
\hline \multirow[t]{2}{*}{ LnEMScore $*$ Tech } & & & & $-0.157 * * *$ \\
\hline & & & & $(-3.83)$ \\
\hline \multirow[t]{2}{*}{ Lnasset } & $0.022 * *$ & $0.021 * *$ & $0.036 * * *$ & $0.036 * * *$ \\
\hline & $(2.51)$ & $(2.50)$ & $(4.39)$ & $(4.38)$ \\
\hline \multirow[t]{2}{*}{$C D$} & 0.005 & 0.006 & $-0.074 * * *$ & $-0.072 * * *$ \\
\hline & $(0.90)$ & $(1.06)$ & $(-13.48)$ & $(-13.14)$ \\
\hline \multirow[t]{2}{*}{ Lev } & $0.118 * * *$ & $0.113 * *$ & $-0.824 * * *$ & $-0.839 * * *$ \\
\hline & $(2.58)$ & $(2.48)$ & $(-12.40)$ & $(-12.60)$ \\
\hline \multirow[t]{2}{*}{$S D$} & $-0.002 * * *$ & $-0.002 * * *$ & $-0.002 * * *$ & $-0.002 * * *$ \\
\hline & $(-4.28)$ & $(-4.23)$ & $(-3.32)$ & $(-3.38)$ \\
\hline \multirow[t]{2}{*}{$P G$} & $0.002 * *$ & $0.002 * *$ & $0.001 *$ & $0.001 *$ \\
\hline & $(2.08)$ & $(2.08)$ & $(1.79)$ & $(1.81)$ \\
\hline \multirow[t]{2}{*}{ Salesgrowth } & $-0.001 *$ & $-0.001 *$ & $0.001 *$ & $0.001 *$ \\
\hline & $(-1.89)$ & $(-1.86)$ & $(1.93)$ & $(1.87)$ \\
\hline \multirow[t]{2}{*}{ Age } & $-0.010^{* * *}$ & $-0.010 * * *$ & $-0.010 * * *$ & $-0.010 * * *$ \\
\hline & $(-6.65)$ & $(-6.65)$ & $(-6.19)$ & $(-6.21)$ \\
\hline \multirow[t]{2}{*}{ Constant } & $-3.458 * * *$ & $-3.499 * * *$ & $-1.552 * * *$ & $-1.686 * * *$ \\
\hline & $(-16.10)$ & $(-16.28)$ & $(-6.69)$ & $(-7.19)$ \\
\hline Year Fx & yes & yes & yes & yes \\
\hline Industry Fx & yes & yes & yes & yes \\
\hline $\mathrm{N}$ & 17855 & 17855 & 17,855 & 17,855 \\
\hline R-squared & 0.1968 & 0.1976 & 0.2238 & 0.2245 \\
\hline Adjusted R-squared & 0.1918 & 0.1927 & 0.2196 & 0.2202 \\
\hline
\end{tabular}

*** $\mathrm{p}<0.01, * * \mathrm{p}<0.05, * \mathrm{p}<0.1 \mathrm{t}$-statistics in parentheses

Second, when classified by technological level, the inhibitory effect of the incentive to hold financial assets on innovation activities is not obvious among enterprises in high-tech industries, whereas the effect of financial risk on innovation 
activities is stronger. The crowding-out effect of the incentive to hold financial assets on innovation activities is stronger in low-tech enterprises and the effect of financial risk on innovation activities is weaker than that in high-tech firms. This study argues that high-tech enterprises have high innovation requirements and for policy reasons, can receive more subsidies or industrial policy support. Hence, their attention to the allocation of financial assets is lower because the incentive to hold financial assets has little impact on their innovation activities. Meanwhile, their operations require a more stable cash flow and their innovation activities are highly uncertain, meaning that financial risk and the stability of financial risk have a greater impact on operations as well as the development of innovation activities. By contrast, low-tech enterprises are not sensitive to long cycles and highly unstable innovation activities and are more likely to shift their limited resources from R\&D to the more profitable capital market, thus causing a significant crowding-out effect on innovation activities.

\subsection{Policy Recommendations}

Based on the empirical findings as well as the real-world problems challenging economic development, this study proposes the following recommendations at the levels of both government and enterprises.

\subsubsection{Government Level}

(1) Improve the financial regulatory system to prevent systemic financial risk: The rapid development of China's financial industry has provided a market environment for real enterprises to participate in financialization. However, it is still in the stage of continuous development and the massive influx of funds from enterprises may increase financial risk. It is thus recommended to improve the financial regulatory system and supervision system to monitor the short-sighted behavior of financialization arbitrage as well as the scale and trend of the financialization of real enterprises to curb financial speculation and prevent systemic financial risk. Avoiding excessive reliance on financial channels for profitability, thereby reducing the enterprise's real business activities and innovation activities

(2) Optimize innovation incentive policies to guide enterprises toward rational innovation: It is recommended to continuously increase support for enterprises' technological innovation and introduce and optimize relevant industrial support policies. Only when the cost of real (innovation) activities is lowered will the upper limit of enterprises' income from participating in the real economy be raised, thus reducing the preference for holding financial assets.

(3) Ease financing constraints to avoid excessive financialization: It is recommended to implement targeted guidance and management for enterprises with different attributes. Among non-SOEs and low-tech enterprises, the financial system that dovetails with their financing gaps should be improved to reduce the excessive preference of non-SOEs to rely on financial markets. 


\subsubsection{Enterprise Level}

When enterprises use the financial market to make investments for profit, they should control the degree of such usage. Enterprises should make reasonable use of the financial market and hold financial assets in an appropriate manner; they should not hold them at the expense of their main business development to avoid the "hollowing out" of their main business. Especially for non-state owned enterprises and high technology enterprises, excessive financial asset allocation and increased corporate financial risk can also further reduce the innovation capability of enterprises.Enterprises should thus set medium- and long-term goals and promote active innovation to support sustainable business operations. China is in a critical period of industrial upgrading, and enterprises, as the main body of industrial transformation, should avoid short-sighted behavior and consciously improve their innovation awareness and capability. For low-tech enterprises, innovation activities should be more in line with the requirements of the long-term development of enterprises, rather than just passive innovation to obtain subsidies, so that innovation and enterprise development can benefit from a virtuous cycle.

\subsection{Limitations}

Owing to sampling limitations and the complexity of the research problem, this study has some limitations. First, we select a sample period of 2009-2019, which incorporates China's accounting system changes and the impact of the global financial crisis on the capital market. Hence, the data do not reflect external influences on enterprises before 2009.

In addition, to strengthen the empirical validity of the incentive to hold financial assets variable, we exclude financial and real estate enterprises from the sample; hence, industry completeness is slightly low. Therefore, the research results may not be generalizable. Real estate enterprises also play a significant role in the capital market. Future empirical research could be conducted on real estate enterprises.

Finally, this study uses a fixed effect model for the panel data regression, controlling for year and industry fixed effects. Whether other factors change the results needs to be further explored. At the same time, in this study, enterprises' ownership type and technological level are selected as moderating variables and macro-level factors, such as macroeconomic policy, financial development level, and economic uncertainty, are ignored. Thus, the model may deviate from the actual situation. Future in-depth studies could address this limitation.

\section{Acknowledgments}

This work was supported by the Gachon University research fund of 2021(GCU202103510001). 


\section{References}

Akkemik, K. A., \& Özen, S. (2014). Macroeconomic and institutional determinants of financialisation of non-financial firms: Case study of turkey. Socio-Economic Review, 12(1), 71-98.

Altman, E. I. (2005). An Emerging Market Credit Scoring System for Corporate Bonds. Emerging Markets Review, 6(4), 311-323.

Altman, E. I. (1968). Financial Ratios, Discriminant Analysis and the Prediction of Corporate Bankruptcy. Journal of Finance, 23(4), 589-609.

Brown, J. R. \& Petersen, B. C. (2011). Cash Holding and R\&D Smoothing. Journal of Corporate Finance, 17(4), 694-709.

Cai, M. R., \& Ren, S. C. (2014). Financialization of Enterprises: A Review of Research. Financial Science, 7, 41-51.

Cai, Z. C., Wu, F., \& Li, H. M. (2018). Financial Asset Allocation Incentive and Enterprise Innovation. Financial Theory and practice, 11, 1-6.

Chen, X. M., \& Zhang, K. X. (2020). Enterprise financial asset allocation and innovation investment: reservoir effect or crowding out effect. Modern Finance and Economics (News of Tianjin University of Finance and Economics), 40(06), 80-98.

Dai, Z., Peng, Y. H., \& Ma, S. C. (2018). Understanding the Economic "Disengagement from real to Virtual" from microcosmic perspective- A review of related research on the financialization of enterprises. Foreign Economy and Management, (11). 31-43.

Gorodnichenko, Y., \& Schnitzer, M. (2011). Financial Constraints and Innovations: Why Poor Countries Don't Catch Up. Journal of the European Economic Association, 11(5), 1115-1152.

Hall, B. (2002). The Financing of Research and Development opment. Oxford Review of Economic Policy, 18(1), 35-51.

Ju, X. S., Lu, D., \& Yu, Y. H. (2013). Financing Constraints, Working Capital Management and Corporate Innovation Sustainability. Economic Research, 1, 4-16.

Krippner, G. R. (2005). The Financialization of the American Economy. Socioeconomic Review, 3(2), 173-208. 
Liu, G. C. (2017). Financial Asset Allocation and Enterprise R\&D Innovation: "crowding out" or "crowding in". Statistical Research, July, 49-61.

Liu, G. C., Liu, Y. Y., \& Zhang, J. (2019). Financial Asset Allocation and Investment volatility of Chinese Listed Companies. Economics (Quarterly), 18(02), 573-596.

Orhangazi, O. (2008). Financialisation and Capital Accumulation in the Nonfinancial Corporate Sector: A the oretical and Empirical Investigation on the US Economy: 1973-2003. Cambridge Journal of Economics, 32(6), 863-886.

Qi, Y. D., \& Zhang, R. Z. (2018). The Empirical Research on the Impact of the Financial Asset Allocation on Firm Value. Finance \&Trade Economics, 39(5), 3852.

Reddy, M. S., Sashikalavathi, A., Kim, H. J., \& Wu,B. F. (2017). Capital Budgeting. International Journal of Smart Business and Technology, 5(1), 11-20.

Reddy, P. S., \& Chowdary, B. N. (2016). Ford Lumban Gaol and Liu Fengli, A Study on Strategies to be Implemented for the Success of a Start-up Company. International Journal of Smart Business and Technology, 4(1), 15-24.

Seo, H. J., Kim, H. S., and Kim, Y. C. (2012). Financialization and the Slowdown in Korean Firms’ R\&D Investment. Asian Economic Papers, 11(3), 35-49.

Song, J., \& Yang, L. (2015). U-shaped Relationship between Non-monetary Financial Assets and Operating Returns: Evidence from Financialization of Listed Non-financial Firms in China. Financial Research, 6, 111-127.

Tori, D., \& Onaran, Ö. (2018). The Effects of Financialization on Investment: Evidence From Firm-level Data for the UK. Cambridge Journal of Economics, 42(5), 1-24.

Wang, H. J., Cao, Y. Q., Yang, Q., \& Yang, Z. (2017). Does Financialization of Real Firms Promote or Inhibit Enterprise Innovation: An Empirical Study based on Chinese Listed Manufacturing Firms. Nankai Management Review, 20(1), 155-166.

Wu, M., \& Wang, C. C. (2018). Has Financial Expansion Hurt the Real Economy: A Theoretical and Empirical Analysis Based on a Two-sector Division Approach. Research in Financial Economics, 33(2), 3-13. 
Xie, J. Z., Wang, W. T., \& Jiang, Y. (2014). Financialization of Manufacturing, Government Control and Technological Innovation, Dynamics of Economics, 11, 78-88.

Zhang, C. S., \& Zhang, B. D. (2016). The Mystery of Declining Industrial Investment Rate in China: An Economic Financialization Perspective. Economic Research, 12, 32-46.

Zhang, X. B. (2017). Research on Financial Risk Management of BL Real Estate Enterprises Based on EMS Early Warning Model, Hebei normal University.

Zhao, L. S., Jin, S. Y., \& Huang, W. D. (2021). Financial Shared Service Center Development in China. Asia-pacific Journal of Convergent Research Interchange, 7(3), 1-17. 